\title{
PRIVATISATION OF NETWORK INDUSTRIES IN GERMANY: A DISAGGREGATED APPROACH
}

\author{
GÜNTER KNIEPS
}

\section{CESIFO WORKING PAPER NO. 1188}

CATEGORY 9: INDUSTRIAL ORGANISATION

MAY 2004

PRESENTED AT CESIFo CONFERENCE ON PRIVATISATION EXPERIENCES IN THE EU NOVEMBER 2003 


\title{
PRIVATISATION OF NETWORK INDUSTRIES IN GERMANY: A DISAGGREGATED APPROACH
}

\begin{abstract}
The purpose of this paper is to analyse the impact of market-oriented institutional reforms in German network industries. A disaggregated approach is chosen, which differentiates between network services, infrastructure management and network infrastructure. The gradual opening of network service provision has already had a positive impact on the performance of all markets for network services. Nevertheless, harmonisation and integration of infrastructure management as well as an adequate regulation of access to the non-competitive infrastructures (monopolistic bottlenecks) is necessary in order to exploit the full benefits of liberalisation and privatisation of network service markets.
\end{abstract}

JEL classification: L33, L50, L97.

\author{
Günter Knieps \\ Albert-Ludwigs-Universität Freiburg \\ Institut für Verkehrswissenschaft und \\ Regionalpolitik \\ Kollegiengebäude II \\ Platz der alten Synagoge \\ 79085 Freiburg \\ Germany \\ guenter.knieps@vwl.uni-freiburg.de
}

The author would like to thank R. Soltwedel, C. Mallin and anonymous referees for constructive comments on earlier versions. 


\section{Institutional reforms of network industries in Germany: A disaggregated approach}

Network industries are typically characterised by different (sub)-parts which strongly complement each other. A large spectrum of different historically grown organisational and institutional structures can be observed, each solving the relevant co-ordination problems in an institutionally different way. For example, although airport owners, airline companies and air traffic control agencies can only jointly guarantee wellfunctioning air traffic, they have been organisationally and institutionally separated ever since the beginning of commercial air traffic. In contrast, it has only been in recent years that an increasing trend towards vertical open network provision of railroad systems, telecommunications networks and electricity systems can be observed. The traditional vertically integrated railroad systems are gradually opening to allow access for alternative service suppliers on European railroad networks. Moreover, a strong tendency towards competition within telecommunications networks can be observed, including service competition and competing network carriers.

In order to provide a differentiated picture of the institutional reforms in network industries, it seems useful to differentiate between the following network levels. 
Level 1: $\quad$ Network services (e.g. air traffic, railway traffic, truck transport, shipping, production and resale of electricity or gas, telecommunications services).

Level 2: $\quad$ Infrastructure management (e.g. air traffic control, railway traffic control).

Level 3: $\quad$ Network infrastructure (e.g. airports, railway infrastructure, transportation and distribution networks of electricity or gas).

The term privatisation has been applied in different meanings. In the broadest sense, privatisation refers to the introduction of market oriented institutional reforms. This includes the sale of publicly owned assets as well as the deregulation of product markets. Privatisation played an important role during the transition process of East Germany (e.g. Sinn, Sinn, 1991). ${ }^{1}$ The focus of this paper, however, is on network industries.

In this paper the role of liberalisation and privatisation ${ }^{2}$ in German network industries is considered for each network level successively, with particular emphasis on the impact of these institutional reforms on the market performance of network services. The topical question to what extent remaining sector specific regulation is still necessary shifts the focus to the vertical problems of the required access of network services to infrastructure management and network infrastructure. Remaining reform potentials therefore also include the vertical perspective of non-discriminatory access to infrastructures complementary to the network service level. However, this does not imply the necessity of an end-to-end regulation. 


\section{The liberalisation process of network services in Germany (level 1)}

\subsection{The EC initiatives}

When the debate on the possibilities of privatisation and deregulation started in the late 1970s and early 1980s, the primary focus was on the network service level. Therefore this reform process has been strongly interrelated to the EC policy of liberalising European service markets.

The debate on the deregulation of transport services in Europe was not only focussed on airlines, trucks and ships, but the role of (potential) entry on European railway networks was also seriously considered. One precedent was set by Foster Yeoman, a stoneproducer in the U.K., which in 1986 purchased its own American diesel locomotives from General Motors for its aggregates trains. In 1989 the EC Commissioner, Karel van Miert, argued in favour of private suppliers of train services. In 1991, the Council of the European Community issued regulation No. 1893/91 on the establishment of railway undertakings or railway rolling stock undertakings in the EC, based on a proposal by the Commission of the European Community.

A cornerstone for the take-off of the development towards competition in European telecommunications markets was the Commission of the European Communities' British Telecom decision in 1982 and its confirmation by the European Court of Justice in 1985. According to this decision, British Telecom should no longer be permitted to forbid the high-speed forwarding of telex messages between foreign countries by competitive agencies in Great Britain. The procedural setting of this case was most unusual because the Italian government and not British Telecom appealed against the Commission's decision. Moreover, the British government intervened, taking sides not with the Italian government, but with the Commission. The important message of the British Telecom case was that the Commission of the European Community was able to apply the Treaty of Rome's competition rules to the European telecommunications administration based on the public law of the different member countries. ${ }^{3}$ 
Since then, the Commission has initiated a wide-ranging discussion of the possibilities of completing the common internal market for telecommunications in the European Community. Obviously, this effort was strongly related to the Commission's endeavour to complete the common market by 1992. The "Green Paper on the Development of the Common Market for Telecommunications Services and Equipment" - issued by the Commission in June $1987^{4}$ - proposed that the provision of terminal equipment as well as enhanced telecommunications services should be liberalised within and between the member countries. ${ }^{5}$ Basic services (mainly voice telephony) as well as the largest parts of the physical networks could still be monopolised by the national telecommunications administrations $;{ }^{6}$ however, arguments concerning the public interest of such a monopoly should periodically be investigated.

It is already well known from normative micro-economic theory as well as from U.S. experience (e.g. Müller, Vogelsang, 1979; Windisch (ed.), 1987; Horn, Knieps, Müller, 1988) that legal entry barriers, administrative price setting, prohibition of cabotage etc. is nothing but a publicly sanctioned monopoly or cartel agreement, and therefore counterproductive from the economic welfare point of view.

Consequences of active and potential competition in the markets for network services are the abolishment of monopoly rents with a subsequent reduction of tariff levels, increasing incentives for cost efficiency, optimisation of service networks, more rapid reaction of prices to changes in the costs and demand structure, increasing price-quality options. From a normative point of view these beneficial effects of entry deregulation and price liberalisation are not only to be expected for the markets for network services in Germany, but also for all other countries liberalising network services.

Nevertheless, the reform process of liberalising network services was strongly pathdependent. Compared to the U.S. deregulation and U.K. privatisation movements in the 1980s the respective developments in Germany have been quite inconspicuous. Several reasons may be mentioned. Among other things, there is the long tradition of "Gemeinwirtschaftslehre", favouring regulation and public enterprises, and the 
institutionalised role of trade unions opposing privatisation and deregulation (Vogelsang, 1988, pp. 195f.). After all, the liberalisation process took nearly two decades, until 1998. In fact, the provision of letter services is still monopolised and the provision of local public transport cannot seriously be called competitive.

\subsection{Liberalisation of different network service markets in Germany}

\subsubsection{Transportation markets}

Tariffs for truck transport in Germany have been liberalised since January 1994, ${ }^{7}$ but it was only after 1998 that entry restrictions by licenses and cabotage prohibitions completely disappeared. The tariffs of the German shipping market were also liberalised in January 1994. Entry and exit were traditionally liberal for ships under German flag, and cabotage prohibition for foreign ships have been gradually liberalised since 1993.

The European airline market was liberalised by the so called three liberalisation packages in 1987, 1990, and 1992, gradually liberalising airline tariffs and market entry for international flights. In accordance with EU liberalisation policy, the German airline market has been liberalised since 1998. Whereas navigation and truck transport services were always provided by private firms, the German national airline company Lufthansa was completely privatised in 1994. Entry deregulation of the airline market, however, was not combined with non-discriminatory access rules to airports. In 1993 the EU adopted the IATA guidelines under Council Regulation No. 95/93, based on the grandfather rights of incumbent airlines.

As regards the railway sector, on January 1, 1994, the „Bahnstrukturreform“ (railway reform) was enacted, based on the report of the „Regierungskommission Bundesbahn“, which was appointed by the government in 1989 (e.g. Ewers, 1994; Boss, Laaser, Schatz et al., 1996; Knieps, 1996). The transition from a public enterprise to a firm under private law in the form of a joint stock company can only be considered a formal privatisation (rather than a real privatisation by sale of publicly owned assets), because the state is still the sole owner of the Deutsche Bahn AG. Separate branches for 
infrastructure, commodity transportation, passenger long-distance transportation and passenger local transportation have been established. The Deutsche Bundesbahn and the Deutsche Reichsbahn, its counterpart in East Germany, suffered from large amounts of debt. The first step of the privatisation process thus consisted of the relief of the liquidation of debts and the endowment with new capital. A major goal of privatisation was entry deregulation of train services in the context of the liberalisation of European transport markets. Accounting separation between service level and infrastructure level was considered a necessary precondition.

\subsubsection{The German telecommunications reform}

The first step of the German telecommunications reform was taken with a new law passed on July $1,1989,{ }^{8}$ restructuring the traditional Deutsche Bundespost (DBP) into three independent enterprises: postal services, telecommunications services and financial services (Postbank), which were then privatised. For telecommunications, the public enterprise DBP Telekom was transformed into the privatised Deutsche Telekom AG in 1995. Although the state still holds about $43 \%$ of the shares, privatisation can be considered to be not only a formal one, because a significant part of the shares are traded at the stock exchanges. Moreover, the government has no golden shares, aiming to ensure that ordinary residential telephone service would continue to be made available as widely as before privatisation. ${ }^{9}$

Privatisation of the former Deutsche Bundespost was accompanied by entry deregulation in two steps. Under the strong influence of the Commission's "Green Paper on the Development of the Common Market for Telecommunications Services and Equipment" ${ }^{\prime 10}$ of June 1987 partial entry deregulation was introduced in European countries. There were controversial debates on the costs and benefits of global entry deregulation. The obstacles to comprehensive entry deregulation did not, however, exclude the possibility of partial entry deregulation. Partial deregulation included free entry into terminal equipment supply and into value added network services (VANS) on the basis of the physical network provided by the network monopolist. 
The "Green Paper on the Liberalisation of Telecommunications Infrastructure and Cable Television Networks" issued by the Commission in October $1994^{11}$ again strongly influenced the process of liberalisation of European telecommunications. The "Full Competition Directive" ${ }^{, 12}$ of 13 March 1996 demanded that member countries permit free entry into all parts of telecommunications. The new telecommunications laws allowing overall market entry were enacted by the national parliaments during 1996, coming fully into effect on 1 January 1998.

\subsubsection{The reform of the German electricity market}

The liberalisation of European electricity markets is based on the EU directive concerning a common electricity market of February 1997 (Directive 96/92/EC), setting a two year target for implementation into national legislation. Germany implemented the directive in April 1998 with the modified Energy Act (Energiewirtschaftsgesetz, EnWG). The aim is to achieve competition at the generation stage as well as at the retail stage. Before that, the electricity sector had been characterised by fully integrated monopolies stabilised by an exemption from the general prohibition on cartels. The supra-regional electricity networks are mainly in private ownership. ${ }^{13}$ On the local / regional level active participation of municipalities can be observed. ${ }^{14}$

In contrast to the other European countries, in Germany privately negotiated frameworks ("association agreements") arranging the conditions for network access have been applied. However, implementing the amendment of the EU directive, which entered into force in July 2003 as directive 2003/54/EC, the revision of the German energy law is currently in its final stage, introducing sector-specific ex ante regulation and extending the competency of what is at present the regulatory agency for telecommunications and postal services. ${ }^{15}$ 


\subsection{The impact of the liberalisation of transportation services on market performance}

An early survey of the impact of the liberalisation of services in different network industries was provided by a study of the Kiel Institute for World Economics in 1996 (Boss et al., 1996). This study demonstrates that the gradual opening of the network service markets has already had a positive impact on the performance of markets for network services. Significant price reductions due to tariff flexibility could be observed in German inland shipping, whereas entry has always been free (Boss et al., 1996, p. 58). After entry deregulation of truck transport prices decreased, service quality increased, and industry efficiency improved. Large price reductions due to tariff liberalisation could be observed in truck transport; during the first year after liberalisation prices already decreased on average by $24 \%$ below the lower tariff borderline of the former regulated long-distance transport tariff (Boss et al., 1996, table 1, p. 97). It has been estimated that in Germany - prior to liberalisation - regulation accounted for excess costs of 30 to $40 \%$ for long-distance truck transport. Increasing competition promoted innovation and encouraged firms to improve their services and develop a wide range of specialised transport services (Boylaud, Nicoletti, 2001, p. 241).

Entry of new airlines to service national lines in Germany started gradually in 1988 (Aero Loyd, Germanwings) and has increased since 1991 (Boss et al., 1996, p. 153). Since the European Single Aviation market in 1997 airline tariffs for international flights within Europe are no longer governed by the price cartel of the IATA-Airlines. ${ }^{16}$ According to an OECD study there is clear evidence that overall efficiency and the rate of occupancy of aircraft seats tend to increase and average fares tend to decrease due to competition; however, only if constraints on airport access are relaxed can the simultaneous liberalisation of the domestic / regional market and international (longdistance) routes result in full network optimisation and cost efficiency (Gönenç,

Nicoletti, 2001, p. 216). ${ }^{17}$ 
As a consequence of airline deregulation in Germany product differentiation increased, a large number of different tariffs were established and the application of yield management was increased. The growing importance of yield management can be illustrated by the pricing strategies of low cost carriers, such as Ryanair, Germania, Germanwings, Hapag-Lloyd and others (e.g. Klophaus, 2003; Schleusener, 2003). The pricing strategies of these newcomers are heterogeneous (see Schleusener, 2003, p. 25). Product differentiation is also strongly dependent on the type of airport the airlines serve. Ryanair, for example, is concentrating on regional airports with a consequent focus on tourists with high price sensitivity, but low time preference. This group of customers is also willing to accept long travel distances to the airport. In contrast, for example Germania is focussing on price sensitive business customers. As a consequence, Germania serves national and international airports; for example, flights are offered between Frankfurt International Airport and Berlin Tegel. On this route, Germania is competing directly with the traditional incumbent Lufthansa as the Bundeskartellamt's recent competition decisions on predatory pricing demonstrate. ${ }^{18}$

Active competition on the German railroad market is focussed on commodity transportation within Germany as well as local passenger transportation. Entry into cross-border transportation can rarely be observed; cabotage on foreign networks within other EU countries does not exist. Competitive subscriptions for subsidies for local passenger transportation take place only to a limited extent (e.g. Aberle, Eisenkopf, 2002, pp. 68 f.).

\subsection{The impact of the liberalisation of the telecommunications markets on performance}

The partial deregulation of the telecommunications sector ${ }^{19}$ already resulted in free entry into terminal equipment supply and value-added network services, employing the physical network of the DBP Telecom monopoly. Moreover, in addition to DBP Telecom two alternative mobile communications providers were licensed. Although the voice telephony market was still monopolised, long distance tariffs were falling by 
about $20 \%$ during the period 1996-1998. Between 1989 and 1994 tariffs for households had already been decreasing by 9.3 \% (Boss et al. 1996, pp. 194f.). This already indicates not only the technological process in the telecommunications sector, but also the increasing instability of partial entry deregulation. Due to the tendency to mix voice and data communications services it became increasingly difficult to differentiate between legally protected voice telephone services and competitive value-added network services (e.g. Knieps, 1989, pp.179f.).

Since the complete entry deregulation of the telecommunications market in 1998 massive private investments in alternative long distance infrastructures have been undertaken and in this area there is now both active and potential competition. At present there are a large number of competitors with their own country-wide long distance networks in Germany. Although the markets for long distance telecommunications services are still frequently characterised by economies of scale and economies of scope, there is nevertheless active and potential competition. ${ }^{20}$ Since overall free entry became possible, the performance of the German long distance telecommunications market has improved strongly: this includes a large number of service providers, providing an increasing scope of services, entry of several network carriers, strongly decreasing prices for long distance calls etc. (cf. Gabelmann, Groß, 2003, pp. 110-121; Stumpf, Schwarz-Schilling, 1999; Immenga et al., 2001, pp. 8-14; Brunekreeft, Groß, 2000; Monopolkommission, 2001, p. 52 ).

The price level for long distance voice telephony decreased substantially during the first years of the global entry deregulation. The development of the price index for long distance services that is reported by Statistisches Bundesamt 1999 and that enters the consumers price index in Germany fell by 41.7 \% between February 1998 and April 1999. A more differentiated view is provided by figure 1 .

Figure 1

After global entry deregulation three types of providers of long distance voice services emerged. The traditional incumbent Deutsche Telekom, alternative network providers ("nationale Vollsortimenter"), which invested heavily in infrastructure, and switch 
based service providers, which hardly invested in infrastructure. During the competition process differences in the price setting behaviour of the different types of firms could be observed. The intense price competition in the winter of 1998/99 not only reduced the overall level of prices, it also resulted in a convergence of prices. The internet and printed media were full of price information, agencies also provided information and the providers themselves advertised aggressively with price as the decisive variable in long distance telecommunications (Brunekreeft, Groß, 2000, p. 932).

The overall development can be summarised as follows (Brunekreeft, Groß, 2000, p. 932): Deutsche Telekom lowered its average price by $62 \%$, the alternative network operators by $66 \%$ and the service providers by $52 \%$ between February 1998 and April 1999. In April 1999 the service providers charged on average only $32 \%$ of what consumers had had to pay to Deutsche Telekom for comparable services 16 months earlier.

After the initial period of strong price decline during 1998/99 the price level began to stabilise. The price for foreign calls was still $36.5 \%$ lower in 2001, as compared to 2000 , and then became stable. In contrast, prices for local access and local calls remained stable (Monopolkommission, 2001, p. 52). ${ }^{21}$

The strong decline of prices for long distance voice telephone services in Germany since global entry deregulation is summarised in figure 2 . These price developments are by no means unique; similar developments can be observed in other European countries.

Figure 2

Whereas Deutsche Telekom held 100\% of the market share for voice telephony before global entry deregulation, the market share of the competitors strongly increased during the period of competition. The competitors' market share (share of traffic volume in minutes) for national long distance calls, including regional calls, increased from 10.3 $\%$ in 1998 to $34.7 \%$ in 2001; the market share for international calls increased from 20 $\%$ in 1998 to $51 \%$ in 2001 (Monopolkommission, 2001, p. 45). ${ }^{22}$ 


\subsection{The impact of the liberalisation of the electricity retail services on market performance}

The deregulation of the electricity market focussed strongly on the role of retail competition. In contrast to most other EU countries Germany opted for complete eligibility from the beginning of liberalisation in April 1998. The development of retail competition focussing on the large group of small domestic and commercial end-users is indicated in figure $3 .^{23}$

\section{Figure 3}

The price developments are divided into incumbents " prices (owner of the distribution network) and entrants ' prices (owner of distribution networks in other areas or pure retailer). Around August 1999 retail competition started reducing the price level significantly. The lowest price level was reached in the spring of 2000. Incumbents reacted immediately. However, since then entrants have left the market or increased their prices. As a consequence, prices went up continuously (Brunekreeft, 2003, pp. 219f.). These developments are shown in figure 4.

\section{Figure 4}

The price developments until the summer of 2000 were considered as an indication of the success of the liberalisation of German electricity markets. The large scale entry of large retail companies (e.g. Yello) and the subsequent price drop attracted substantial attention in the media. After entrants increasingly left the retail markets and prices increased again, public attention shifted to the role of access to electricity networks. In particular, the complaint was that due to excessive access charges the price levels of competitive retailers did not guarantee market survival (Brunekreeft, 2003, p. 219). 


\subsection{The provision of universal services}

The objective of universal service provision by means of subsidisation has been of no relevance for the provision of truck transport services or shipping; furthermore it was of minor interest for airline transportation markets. However, subsidisation of telecommunications, postal services (especially first class mail), train services (in particular local traffic) as well as public transport (ÖPNV) is still politically relevant.

The major reason why global entry deregulation - including voice telephone services as well as network infrastructure - was only introduced in 1998 (nearly twenty years after the slow beginning of deregulation in the early 1980s) was the provision of universal services at socially desired tariffs by means of cross-subsidisation.

In the German telecommunications sector the political process was dominated by a silent coalition between the Deutsche Bundespost (DBP) and its unions on the one hand and the small and peripheral users on the other hand. The DBP and its unions were interested in the monopoly which in turn could only be legitimised and supported politically by the subsidies it provided for the large majority of small and peripheral users at the expense of business users.

Some way had to be found to compensate small and peripheral users for the losses they would incur in the case of complete entry deregulation. Only such an arrangement could secure their support on the issue of telecommunications deregulation. In order to make free entry into all parts of telecommunications politically acceptable, it was proposed to split the silent coalition between the telecommunications administration and the small users by setting up a universal service fund (Blankart, Knieps, 1989). The purpose of this fund was to keep the traditional subsidy of the small users stable, only changing the way it was financed from internal to external subsidisation. In order to make sure that the small users do not oppose deregulation it seems to be important to guarantee the price-level of the traditionally internally subsidised services as upper boundary ("social contract" pricing). 
Under a universal service fund every chosen supplier of a subsidised service has the right to obtain an external subsidy, financed out of this fund. The amount of subsidy depends on the difference between the incremental costs of providing the socially desired services and the "social-contract" prices. The competition for subsidies also reveals the actual burden of the universal services and the minimum costs of traditionally internally subsidised services. It cannot be expected that the traditional carrier is necessarily the most cost-effective supplier, if new firms with cost-saving technologies (e.g. mobile telephone and microwave systems) enter the market. Therefore, the bidding for the subsidised markets may strongly reduce the volume of subsidies required. In particular, an increase of the universal service fund to finance the traditionally internally subsidised services can be excluded as long as the scope of universal services is not extended (Blankart, Knieps, 1989).

One possibility of financing the required subsidies would be the public budget. This is still the case in public transport; for telecommunications and postal services, however, the concept of an entry tax has been proposed, which all suppliers of lucrative activities (incumbent and competitors) would have to pay. The concept of a universal service fund was introduced in the new German Telecommunications law enacted in 1996 (as well as in many other European countries). The concept was also introduced in the new postal law.

Until now, no universal service fund has been implemented in Germany. In contrast, in the U.S. a universal service fund was established. The size of this universal service fund became rather large, because not only the traditional cross-subsidised narrow-band services in rural areas, but also cost-intensive new services, including broad-band internet access for schools and libraries as well as health care providers were included (CC Docket No. 96-45, In the Matter of Federal-State Joint Board on Universal Service, May 8, 1997, in particular pp. 227, 318; April 10, 1998). Contributions to the federal universal service support mechanisms are determined using a quarterly contribution factor calculated by the Federal Communications Commission. For example, projected program support for the fourth quarter 2003 was 1.599725 billion \$ (schools and libraries: 0.551197 billion \$), which was related to total projected collected interstate 
and international end-user telecommunications revenues of 18.607282 billion $\$$ for the fourth quarter 2003, resulting in a proposed contribution factor of 0.092 (Universal Service Contribution Factor, CC Docket No. 96-45, September 5, 2003)

The instrument of a competitive bidding procedure for subsidised public transportation services (transparent and non-discriminatory subscription procedures) was implemented legally during the reform of the railway services. Today the implementation of the "Bestellerprinzip" focussing on ex ante bidding for subsidies from the public budget, instead of ex post, ad hoc subsidy requirements is the leading concept in EU transportation policy (although its implementation in practice does not always seem to be an easy task).

\section{Reform of infrastructure management (level 2)}

The importance of co-ordination and allocation activities of network capacities varies strongly between different network industries. Although the liberalisation of the network services increases co-ordination efforts, truck transport and shipping has rarely been co-ordinated in the past, but the current implementation of toll collect in Germany for heavy trucks shows the increasing importance of infrastructure management for road traffic also.

In contrast, air traffic control has a long tradition in infrastructure management. It is well-known that air transport services not only require airports and planes, but also air traffic control systems. Air traffic control systems not only have the task to guarantee traffic safety, but are also responsible for an efficient allocation of airspace capacity. Although airport owners, airlines and air traffic control agencies can only jointly guarantee a well-functioning air traffic, they are organisationally and institutionally separated. 
The permanent control and co-ordination of traffic is also necessary for train services. Train control systems are therefore the decisive link between rails and stations on the one hand and the supply of train services on the other hand. This co-ordination effort depends on the number of trains, the sequencing of faster and slower trains as well as their speed, but is not influenced by the number of train companies that are active on a certain railroad network. Moreover, the cost of train control does not increase when train control systems are organisationally separated from the tracks. The scheduling and operating of trains as well as the repair of rails has to be co-ordinated by train control systems, irrespective of whether they are vertically integrated with the tracks and station infrastructure or not. Recent technological developments in advanced train control systems and high-speed computers have provided ample opportunities to automate many functions in scheduling and operating railroads. Thus, train traffic control systems are developing towards highly software-oriented technical systems with a large potential of transborder-oriented scale. Similar to air traffic control, possibilities arise for an integrated Europe-wide train traffic control system, harmonising train schedules and coordinating train movements on a Europe-wide scale. Compared with the current train co-ordination policy, which is strongly geared to the national or regional levels, large efficiency benefits can be expected.

The strong national orientation of the capacity management of track capacities was caused by the traditional national railroad monopolies. Transborder orientation within the international union of railways (UIC) has been minimised with respect to standardisation (e.g. Knieps, 1995). Therefore, optimisation is strongly limited to national railroad systems. A long-term objective could be the founding of a European train traffic control agency responsible for the co-ordination of Europe-wide train services. Such a development could be strongly stimulated by separating train control from national rail infrastructure policies.

Although air traffic control in Europe is much more integrated than train traffic control, the allocation of airspace is in the competence of the individual countries. Eurocontrol has no final authority, its board, the permanent commission, is composed of the transport ministers of the member countries. National boundaries and the objective of 
retaining the sovereignty of the individual countries have led to arbitrary inefficient horizontal divisions. According to a study by Eurocontrol (2002, p. 35) cost of delays, due to air traffic flow management, are estimated to be between 2500 to 3600 million $€$ (total airspace user costs and cost of passengers). In the meantime, reform proposals by the European Commission are focussing on the creation of a single European upper airspace by merging the current national regions (European Commission, 2002, p. 9).

In Germany, formal privatisation of the air traffic control organisation into Deutsche Flugsicherungs GmbH /DFS took place in January 1993. The cost of this organisation has to be covered (similarly to Eurocontrol) by user charges. The efficiency effects of formal privatisation are not known (e.g. Boss et al., 1996, p. 174). Whereas until the year 2000 the revenues were sufficient to cover costs, in the years 2001 and 2002 a deficit of 33.380 million $€$ and 21.466 million $€$, respectively, occured (Deutsche Flugsicherung, 2003, p. 2).

Since traffic control systems are natural monopolies, which need public authority to define the scope and borderlines of the control areas, selective free entry into the control business is not feasible and would lead to disaster. Nevertheless, competitive bidding to find the most efficient traffic control agency for a well defined control area can be expected to work. ${ }^{24}$ If bidding took place Europe-wide, a process of competition among institutions would occur. As a consequence, the agency with the most innovative software and control system might also be successful in providing traffic control services in other countries.

Since the liberalisation of the electricity sector the co-ordination between electricity generation and transmission has become increasingly important. ${ }^{25}$ In the meantime, in continental Europe transborder high-voltage transportation by means of transborder interconnectors as well as the evolution of markets for balancing power („Regelenergie“) have become major issues. Due to the important role of system externalities (based on Kirchhoff's laws, which state that it is the characteristic of electricity to seek the path of least resistance) there seems to be a large co-ordination potential of transborder electricity flows between European countries, which until now 
seems rather unexploited (e.g. Zimmer, 2004). Co-ordination efforts also play a role in telecommunications, e.g. standardisation, telephone numbering, and spectrum allocation. Such efforts to define and allocate property rights should, however, be differentiated from permanent control and the co-ordination of traffic flows.

\section{Reforms of allocation of network infrastructure capacities (level 3)}

The more the aim of liberalising network services succeeded (entry deregulation, price deregulation etc.), the more did the focus of EC directives as well as the national sectorspecific laws shift to the problems of access to network infrastructure.

\subsection{The reform process}

In Germany the new telecommunications law, together with a decree on special access, was passed in 1996. This new telecommunications law is currently under review, focussing on the scope of future regulation as well as the adequate regulatory instruments (e.g. Vogelsang, 2003). The new German energy law was passed in 1998. In contrast to all other European countries German legislation opted for allowing negotiated third party access within the association agreements for network access. A revision of this law is now in its final stage introducing regulated third party access. The German railroad reform of 1993 is currently also under review focussing on the introduction of sector specific access regulation. Grandfather rights to airport slots are also under attack in the context of the current review of the EU Council Regulation No. 95/93 on allocation of airport slots from 1993, which at that time did not allow marketbased instruments such as slot exchange and slot auction (e.g. Boyfield, 2003, p. 34).

In contrast to the provision of network services state ownership on the infrastructure level still plays an important role in Germany. Highways are owned by the state, 
German railways are only formally privatised. Airports are to a large extent owned by the state, but increasingly private capital is attracted. Since 1997 the heavily used (congested) airports Düsseldorf and Frankfurt, and subsequently Hamburg and Hannover have been partly privatised („Teilprivatisierung“) (e.g. Brunekreeft, Neuscheler, 2003, p. 260). ${ }^{26}$ Since private capital can only be raised if risk-equivalent interest rates can be expected, privatisation shifted public attention to the cost covering possibilities of access charges to the infrastructure.

Infrastructure of telecommunications networks is mainly owned by private firms (although the state still owns a large part of the shares of Deutsche Telekom). Private shares have a strong tradition in electricity and gas networks. The long distance networks for gas transportation are owned by private firms. On the local / regional level, however, this picture changes due to the active participation of municipalities.

Vertical separation in terms of ownership between the different network levels did not occur in German network industries, irrespective of the ownership structure (private or public), before the liberalisation process started. However, in the railroad sector there has been an intense controversy on the issue of separating railway infrastructure from railway services and not only formally privatising the service companies of the Deutsche Bahn AG (e.g. Knieps, 1996, p. 44; Wissenschaftlicher Beirat beim Bundesministerium für Verkehr, 1997, p. 632). This, nevertheless, did not succeed so far.

\subsection{Remaining reform potentials}

The reform potentials on the level of network infrastructure and the remaining regulatory problems centre around the basic question whether the providers of network services need access to a network infrastructure with characteristics of a monopolistic bottleneck (e.g. Knieps, 1997, p. 327). Remaining reform potentials therefore centre around the vertical perspective of non-discriminatory access to infrastructures 
complementary to the network service level. However, this does not imply the necessity of an end-to-end regulation including the competitive segments.

The conditions necessary for a monopolistic bottleneck facility are fulfilled

(1) if a facility is essential in order to reach customers, i.e. if there is no second or third such facility, in other words if no active substitute is available. This is the case if, due to bundling advantages, there is a natural monopoly situation, meaning that one supplier can make the facility available more cost-efficiently than several suppliers;

(2) and if at the same time the facility cannot be duplicated on reasonable economic terms, i.e. if there is no potential substitute available. This is the case if the facility's costs are irreversible and if, as a result, there is no functioning second hand market for these facilities.

The criterion for the localisation of the remaining sector-specific need for regulation within network infrastructures is always the question whether access to these facilities is an indispensable prerequisite for offering a complementary service at an upstream or downstream production level. It is therefore necessary to ensure non-discriminatory access to the bottleneck through tailor-made bottleneck regulation. In all other network areas, however, the situation is completely different because there is active and potential competition.

The bottleneck theory is not a theory developed specifically for a single network sector. Whereas there are no monopolistic bottlenecks on the level of network services and infrastructure management, monopolistic bottlenecks do exist on the infrastructure level. Examples are: airports, railway infrastructure, electricity transmission and distribution networks. Nevertheless, not every network infrastructure does possess the characteristics of a natural monopoly in combination with irreversible costs. For example, supra-regional high-pressure gas pipeline transmission in Germany is not a monopolistic bottleneck, due to the broad competition potential created by pipelines operated by project companies, through ownership in undivided shares and through access options to competing backbone pipelines (Knieps, 2002). Long-distance 
telecommunications networks are characterised by the existence of alternative network providers and the remaining bottleneck problem is limited to the local loop (e.g. Knieps, 1997, pp. 331f.; Laffont, Tirole, 2000, p. 98). Compared to other European countries (e.g. Switzerland, Great Britain) in Germany developments of inter-active cable TV networks are still at an early stage. A major reason for this slow development can be found in the institutional separation of the vertical industry structure, in particular the separation between the local access points and the subsequent in-house provisions (e.g. Distelkamp, 2000, p. 4).

Competitive network infrastructures do not create regulatory problems. Due to network alternatives the problem of avoiding discriminatory access disappears; incentives do exist for efficient allocation of network capacities; excessive profits cannot be expected; and the subsidy problem disappears.

Regulating those parts of network infrastructures characterised as monopolistic bottlenecks remains an important task even after full market opening. Where network sectors have monopolistic bottleneck areas, they need specific regulation to discipline remaining market power. This requires, above all, symmetric access to the monopolistic bottleneck areas for all active and potential providers of network services to allow (active and potential) competition to fully develop. Moreover, price cap regulation should be applied, limited to the monopolistic bottleneck areas.

There are still network infrastructures remaining where access charges do not allow cost covering. The provision of infrastructure investments in streets, canals, airports, and rails has traditionally been considered a typical task of the state. As long as the usage of the infrastructure is so low that there is non-rivalry, market prices do not make sense and the state plays a significant role in guaranteeing its finance. The introduction of time- and capacity-dependent landing fees or railroad access charges significantly improves the financing of the infrastructure costs. Nevertheless, it seems important that public subsidies to guarantee cost cover requirements of infrastructures with low demand ("Infrastrukturvorhaltefunktion") should only be granted as a result of a transparent political process. 


\section{Conclusions}

When the debate on the possibilities of privatisation and liberalisation started in the late 1970s and early 1980s, the primary focus was on the network service level. Therefore this reform process has been strongly interrelated to the EC policy of liberalising European service markets. Nevertheless, the reform process of liberalising network services was strongly path-dependent. After all, the liberalisation process took nearly two decades.

The gradual opening of the network service markets has already had a positive impact on the performance of markets for network services. Significant price reductions due to tariff flexibility could be observed in German inland navigation, whereas entry has always been free. Large price reductions due to tariff liberalisation could be observed in truck transport. After entry, deregulation prices decreased, service quality increased, and industry efficiency improved. Increasing competition promoted innovation and encouraged firms to improve their services and develop a wide range of specialised transport services. As a consequence of airline deregulation in Germany product differentiation increased, a large number of different tariffs were established and the application of yield management was increased. The price level for long distance voice telephony decreased substantially during the first years of global entry deregulation. After the initial period of strong price decline during 1998/99 the price level began to stabilise.

The more the aim of liberalising network services succeeded (entry deregulation, price deregulation etc.), the more did the focus of EC directives as well as the national sectorspecific laws shift to the problems of infrastructure management and access to network infrastructure, and in particular to the future role of sector-specific regulation of the remaining network-specific market power. Therefore, it seems useful to differentiate 
between network services, infrastructure management, and the (non-competitive) monopolistic bottleneck areas of the network infrastructure.

Since the complete entry deregulation of the telecommunications market in 1998 massive private investments in alternative long distance infrastructures have been undertaken and in this area there is now both active and potential competition. In contrast, airports and railway infrastructures are monopolistic bottlenecks, with the need for adequate access regulation. In the meantime there is an intense debate on introducing a market for slots, focussing on non-discriminatory and efficient allocation of airport capacities. Ex ante regulation of non-discriminatory access to railway infrastructures is currently under review and should lead to improved competition on markets for railway traffic. In addition, the current reform proposals by the European Commission are focussing on the harmonisation and integration of infrastructure management, in order to overcome the strong national orientation of the infrastructure management. These efforts are also intended to contribute to increased efficiency on the European transportation markets.

Electricity transmission networks are also monopolistic bottlenecks, without active and potential competition on the level of infrastructure. The deregulation of the electricity market focussed strongly on the role of retail competition but ignored the role of access regulation to ensure this competition. The comparison of retail prices of incumbent firms and market entrants as well as the market exit of the new competitors has been a result of this shortfall. Currently, with the installation of a regulatory authority, public attention shifts to the future role of access regulation of electricity networks. 


\section{Bibliography}

Aberle, G., Eisenkopf, A. (2002), Schienenweg und Netzzugang -

Regulierungsprobleme bei der Öffnung des Schienennetzes und wettbewerbspolitische Empfehlungen zur Gestaltung des Netzzugangs, Hamburg: Deutscher Verkehrs-Verlag

Blankart, Ch.B., Knieps, G. (1989), What Can We Learn From Comparative Institutional Analysis? The Case of Telecommunications, Kyklos 42, 579-598

Bös, D. (1993), Privatization in Europe: a comparison of approaches, Oxford Review of Economic Policy 9/1, 95-111

Boss, A., Laaser, C.-F., Schatz, K-W., et al. (1996), Deregulierung in Deutschland Eine empirische Analyse, Kieler Studien 275, Tübingen: J.C.B. Mohr (Paul Siebeck)

Boyfield, K. (2003), Who owns airport slots? A market solution to a deepening dilemma, in: Boyfield, K. (ed.), A Market in Airport Slots, The Institute of Economic Affairs, London, 21-50

Boylaud, O., Nicoletti, G. (2001), Regulatory Reform in Road Freight, OECD Economic Studies 32, 229-251

Brunekreeft, G. (1997), Co-ordination and Competition in the Electricity Pool of England \& Wales, Baden-Baden: Nomos Verlag

Brunekreeft, G. (2003), Regulation and Competition Policy in the Electricity Market Economic Analysis and German Experience, Baden-Baden: Nomos Verlag

Brunekreeft, G., Groß, W. (2000), Prices for long-distance voice telephony in Germany, Telecommunications Policy 24, 929-945

Brunekreeft, G., Keller, K. (2000), The electricity supply industry in Germany: market power or power of the market?, Utilities Policy 9, 15-29

Brunekreeft, G., Neuscheler, T. (2003), Preisregulierung von Flughäfen, in: Knieps, G., Brunekreeft, G. (Hrsg.), Zwischen Regulierung und Wettbewerb - Netzsektoren in Deutschland, Heidelberg: Physica-Verlag, 2. Auflage, 251-280

Deutsche Flugsicherung (2003), Geschäftsbericht 2002, Langen 
Distelkamp, M. (2000), Wettbewerbspotenziale der deutschen Kabel-TV-Infrastruktur, Wissenschaftliches Institut für Kommunikationsdienste (WIK), Diskussionsbeitrag Nr. 203, Bad Honnef

Ergas H. (1996), Telecommunications Across the Tasman: A Comparison of Regulatory Approaches and Economic Outcomes in Australia and New Zealand, University of Auckland, 15 May 1996

Eurocontrol (2002), Performance Review Report, An Assessment of Air Traffic Management in Europe during the Calendar Year 2001, Brussels

European Commission (2002), A single European sky, Broadening horizons for air travel, Brussels

Ewers, H.-J. (1994), Privatisierung und Deregulierung bei den Eisenbahnen - Das Beispiel der Deutschen Bundesbahn und der Deutschen Reichsbahn, Jahrbuch für Neue Politische Ökonomie 13, 178-208

Gabelmann, A., Groß, W. (2003), Telekommunikation: Wettbewerb in einem dynamischen Markt, in: Knieps, G., Brunekreeft, G. (eds.), Zwischen Regulierung und Wettbewerb - Netzsektoren in Deutschland, Heidelberg, Physica-Verlag, 2. Auflage, 85-130

Gerber, P. (2002), Success factors for the privatisation of airports - an airline perspective, Journal of Air Transport Management 8, 29-36

Gönenç, R., Nicoletti, G. (2001), Regulation, Market Structure and Performance in Air Passenger Transportation, OECD Economic Studies, No. 32, Paris, 183-227

Horn, M., Knieps, G., Müller, J. (1988), Die gesamtwirtschaftliche Bedeutung von Deregulierungsmaßnahmen in den USA: Schlußfolgerungen für die Bundesrepublik Deutschland, Baden-Baden: Nomos-Verlag

Immenga, U., Kirchner, C., Knieps, G., Kruse, J. (2001), Telekommunikation im Wettbewerb - Eine ordnungspolitische Konzeption nach erfolgreicher Marktöffnung, München: Verlag C.H. Beck

Kay, J.A., Thompson, D.J. (1986), Privatisation: A Policy in Search of a Rationale, The Economic Journal 96, 18-32

Klophaus, R. (2003), Vielfliegerprogramme für Low-cost Airlines, Zeitschrift für Verkehrswissenschaft 74/2, 115-128 
Knieps, G. (1989), Telecommunications Policy - Assessing Recent Experience in the US, Japan and Europe and its Implications for the Completion of the Common Market, in: Giersch, H. (ed.), Services in World Economy, Symposium 1988, Tübingen: J.C.B. Mohr (Paul Siebeck),173-189

Knieps, G. (1995), Standardization: The Evolution of Institutions versus Government Intervention, in: Gerken L. (ed.), Competition Among Institutions, London: MacMillan Press, 283-296

Knieps, G. (1996), Wettbewerb in Netzen - Reformpotentiale in den Sektoren Eisenbahn und Luftverkehr, Tübingen: J.C.B. Mohr (Paul Siebeck) Knieps, G. (1997), Phasing out Sector-Specific Regulation in Competitive Telecommunications, Kyklos 50/3, 325-339

Knieps, G. (2002), Wettbewerb auf den Ferntransportnetzen der deutschen Gaswirtschaft - Eine netzökonomische Analyse, Zeitschrift für Energiewirtschaft 26/3, 171-180

Laffont, J.-J., Tirole, J. (2000), Competition in Telecommunications (The Munich Lectures), Cambridge, Massachusetts: MIT Press

Monopolkommission (2001), Wettbewerbsentwicklung bei Telekommunikation und Post 2001: Unsicherheit und Stillstand, Sondergutachten, Bonn Müller, J., Vogelsang, I. (1979), Staatliche Regulierung - Regulated Industries in den USA und Gemeinwohlbindung in wettbewerblichen Ausnahmebereichen in der Bundesrepublik Deutschland, Baden-Baden: Nomos-Verlag RWE (2003), Facts and Figures. www.rwe.com

Schleusener, M. (2003), Low Cost Airlines: Focus on Pricing, Präsentationsfolien von Simon, Kucher \& Partners, Köln, 20. Januar 2003 http://www.wiso.uni-koeln.de/marketing/Vortrag_schleusener.pdf Schulte-Braucks, R. (1986), Das ,British Telecom‘-Urteil: Eckstein für ein europäisches Fernmelderecht?, Wirtschaft und Wettbewerb 3, 202-215

Sinn, G., Sinn, H.-W. (1991), Kaltstart: Volkwirtschaftliche Aspekte der deutschen Vereinigung, Tübingen: J.C.B. Mohr (Paul Siebeck)

Stumpf, U., Schwarz-Schilling, C. (1999), Wettbewerb auf Telekommunikationsmärkten, Diskussionsbeitrag Nr. 197, Wissenschaftliches Institut für Kommunikationsdienste, Bad Honnef 
Vogelsang, I. (1988), Deregulation and Privatization in Germany, Journal of Public Policy, 8, 195-212

Vogelsang, I. (2003), The German Telecommunications Reform - Where did it come from, Where is it, and Where is it Going?, Perspektiven der Wirtschaftspolitik, $4 / 3,313-340$

Windisch, R. (ed.) (1987), Privatisierung natürlicher Monopole im Bereich von Bahn, Post und Telekommunikation, Tübingen: J.C.B. Mohr (Paul Siebeck)

Wissenschaftlicher Beirat beim Bundesministerium für Verkehr (1997),

Bahnstrukturreform in Deutschland - Empfehlungen zur weiteren Entwicklung. Stellungnahme vom November 1997, Internationales Verkehrswesen, 49, 626-633

Zimmer, C. (2004), Knappe Interkonnektorkapazitäten - Wie löst man die „Stauprobleme“ im europäischen Höchstspannungsnetz?, Schriftenreihe der Deutschen Verkehrswissenschaftlichen Gesellschaft: Versteigerungen und Ausschreibungen inVerkehrs- und Versorgungsnetzen - Praxiserfahrungen und Zukunftsperspektiven, Reihe B, B 272, Berlin, 121-134 
1 The agency which has been in charge of privatisation was the "Treuhandanstalt". In East Germany, 4.223 out of 12.036 key-sector enterprises were totally privatised between 3 October 1990 and 31 July 1992; moreover, 3.981 parts of enterprises were privatised with a minority participation of the "Treuhandanstalt" (Bös, 1993, p. 98).

2 In this paper the term privatisation is used in its most common sense as sale of publicly owned assets (e.g. Kay, Thompson, 1986), in contrast to deregulation.

3 For a detailed explanation of this case see Schulte-Braucks, 1986, pp. 202-215.

$4 \quad$ KOM (87) 290 fin.

5 In addition, the Commission pleaded for a liberalisation of the procurement policy of the national telecommunications administration as well as for an introduction of European-wide telecommunications standards.

6 Only the margins of the physical networks (mobile radio and low speed satellite communication) were opened for competition.

7 Tarifaufhebungsgesetz vom 13. August 1993.

8 Gesetz zur Neustrukturierung des Post- und Fernmeldewesens und der Deutschen Bundespost (Poststrukturgesetz) vom 8. Juni 1989, Bundesgesetzblatt Teil I vom 14. Juni 1989, pp. 1026-1051.

9 Such golden shares called "Kiwi Shares" were introduced for example during the privatisation process in New Zealand (e.g. Ergas, 1996).

10 KOM (87) 290 fin.

11 KOM (94) 440 fin.

12 Commission Directive 96/19/EC of 13 March 1996 amending Directive 90/388/EEC with regard to the implementation of full competition in the telecommunications markets, OJ L 74, 22. 3. 1996, p. 13 (the "Full Competition Directive").

13 Private shareholders (including institutional shareholders like insurance companies) hold $67 \%$ of the shares and municipals hold $33 \%$ of the shares of RWE AG (cf. RWE, 2003, p. 182). 
14 Details on the German electricity sector can be found in Brunekreeft, Keller, 2000, p. 16 and Brunekreeft, 2003, p. 135.

15 Entwurf eines Gesetzes zur Neufassung des Energiewirtschaftsrechts (27. Februar 2004). The future regulatory agency will be called „Regulierungsbehörde für Elektrizität, Gas, Telekommunikation und Post (REGTP).

16 The bulk of international routes outside Europe is still governed by restrictive bilateral air service agreements (ASA's) (e.g. Gönenç, Nicoletti, 2001, pp. 188, 221).

17 The problem of non-discriminatory access to airport slots will be considered in section 3 .

18 Bundeskartellamt, 9. Beschlusskammer, B9 - 144/01, 18. Februar 2002. In this context the role of reallocation of scarce airport slots and the subsequent challenge of "grandfathering" could be observed (Bundeskartellamt, 9. Beschlusskammer, B9 $-62100-Z-75 / 02,7$. August 2002) (see section 3) .

19 Voice telephony which accounts for ca. $85 \%$ of total returns as well as network infrastructure remained monopolised until January 1998.

20 The required non-discriminatory access to the complementary local networks, including number portability, has been granted by sector specific regulation.

21 See Statistisches Bundesamt, Verbraucherpreisindex für Telekommunikationsdienstleistungen, Mitteilung Nr. 41 vom 31. Januar 2001.

22 At that time no preselection and call-by-call were available for local calls.

23 For detailed analysis see Brunekreeft, Keller (2000), pp. 22f. and Brunekreeft (2003) pp. $218 f$.

24 Network specific market power due to the absence of significant sunk cost cannot be expected (see also next section).

25 For the experience of co-ordination in the electricity pool of England and Wales see e.g. Brunekreeft, 1997.

26 The share of private capital in Düsseldorf is $50 \%$, in Frankfurt $28.97 \%$, in Hamburg $36 \%$ and in Hannover $30 \%$ (Gerber, 2002, p. 31). 
Figure 1: Average prices for the three types of providers

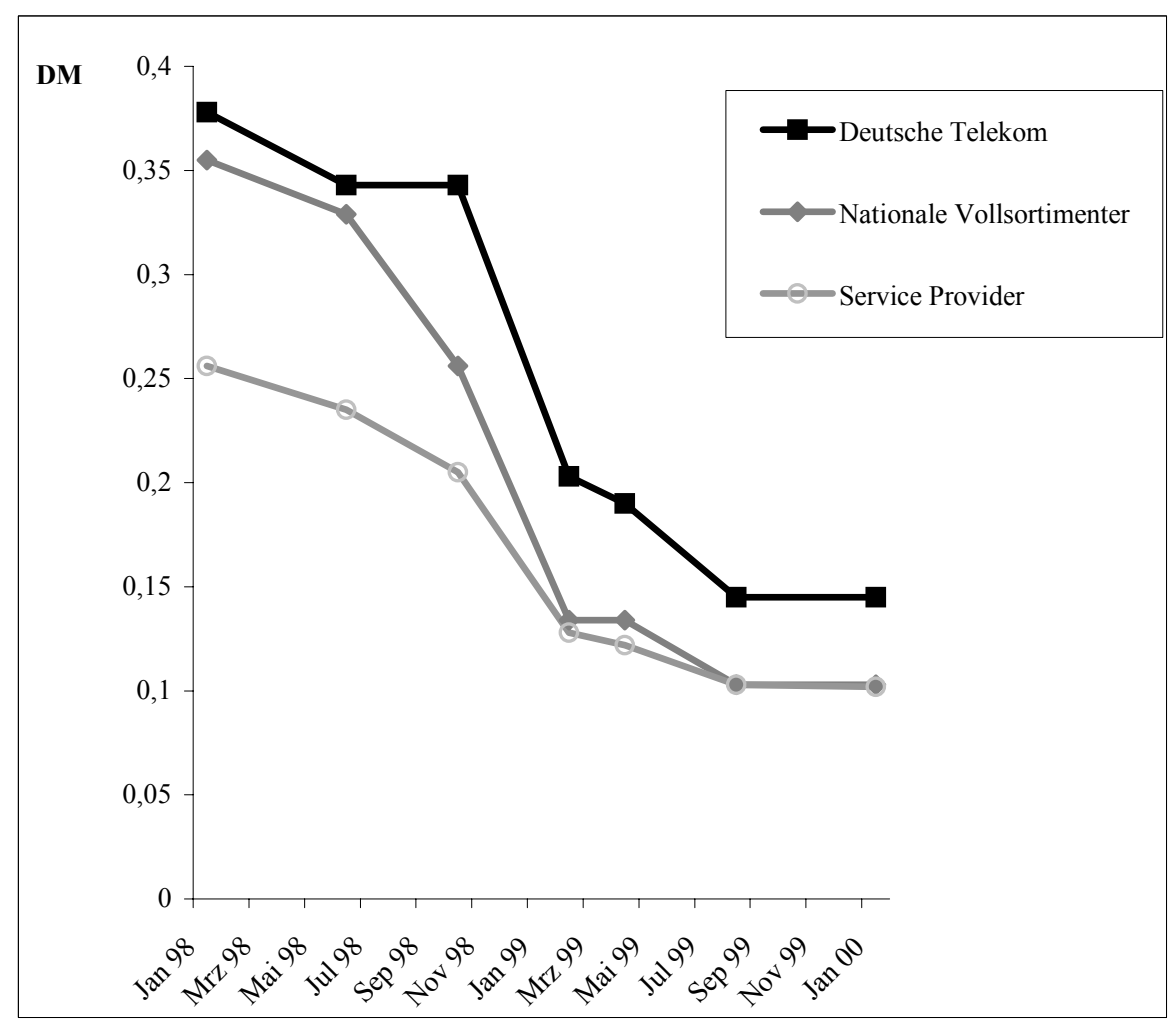

Source: Gabelmann, Gross (2003), p. 116 
Figure 2: $\quad$ Minimal tariffs for national long distance calls in fixed networks (date: 9 January 2003)

Standard tariffs, discounts excluded Prices in cent per minute, weekdays, call-by-call

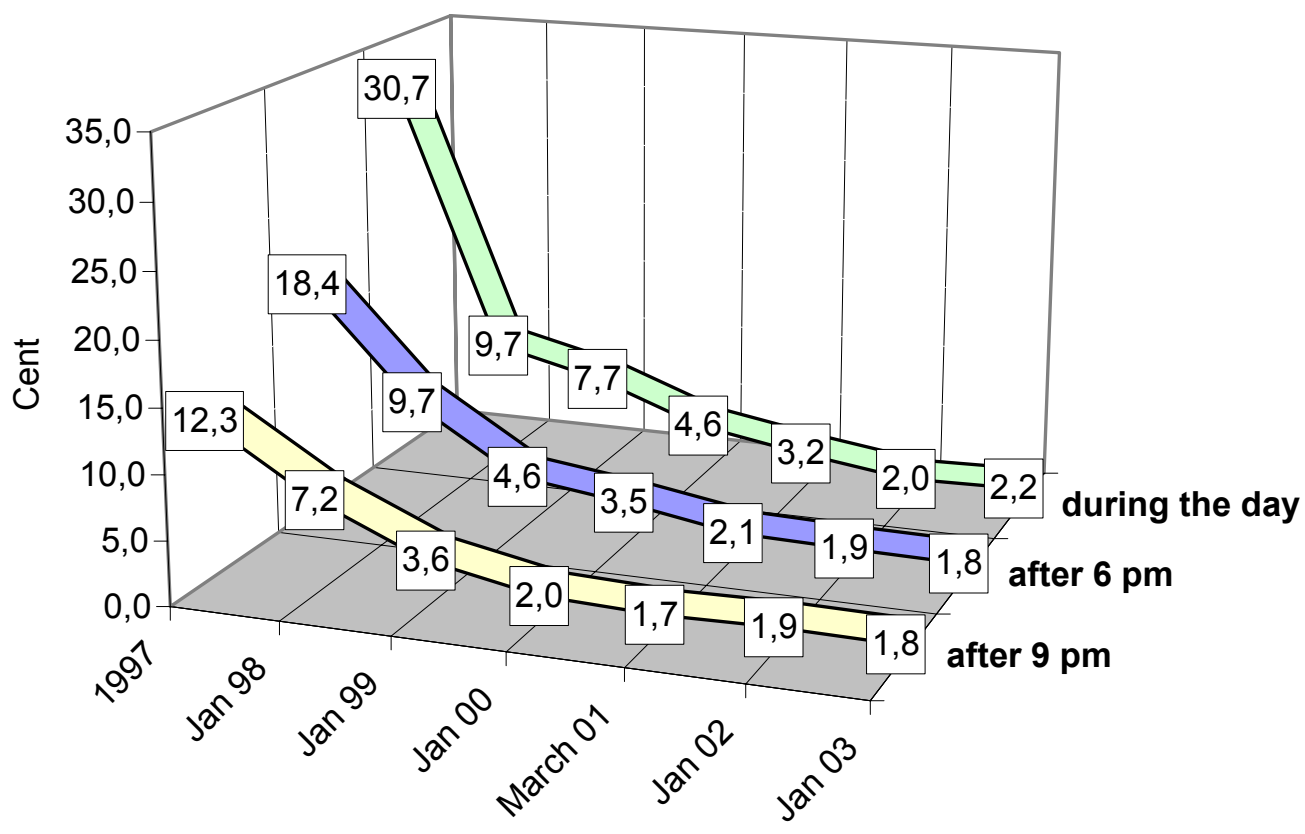

Source: Jahresbericht 2002, Marktbeobachtungsdaten der Regulierungsbehörde für Telekommunikation und Post, p. 23. 
Figure 3: Development of electricity prices for residential users (with an annual consumption of $3.500 \mathrm{kWh}$ )

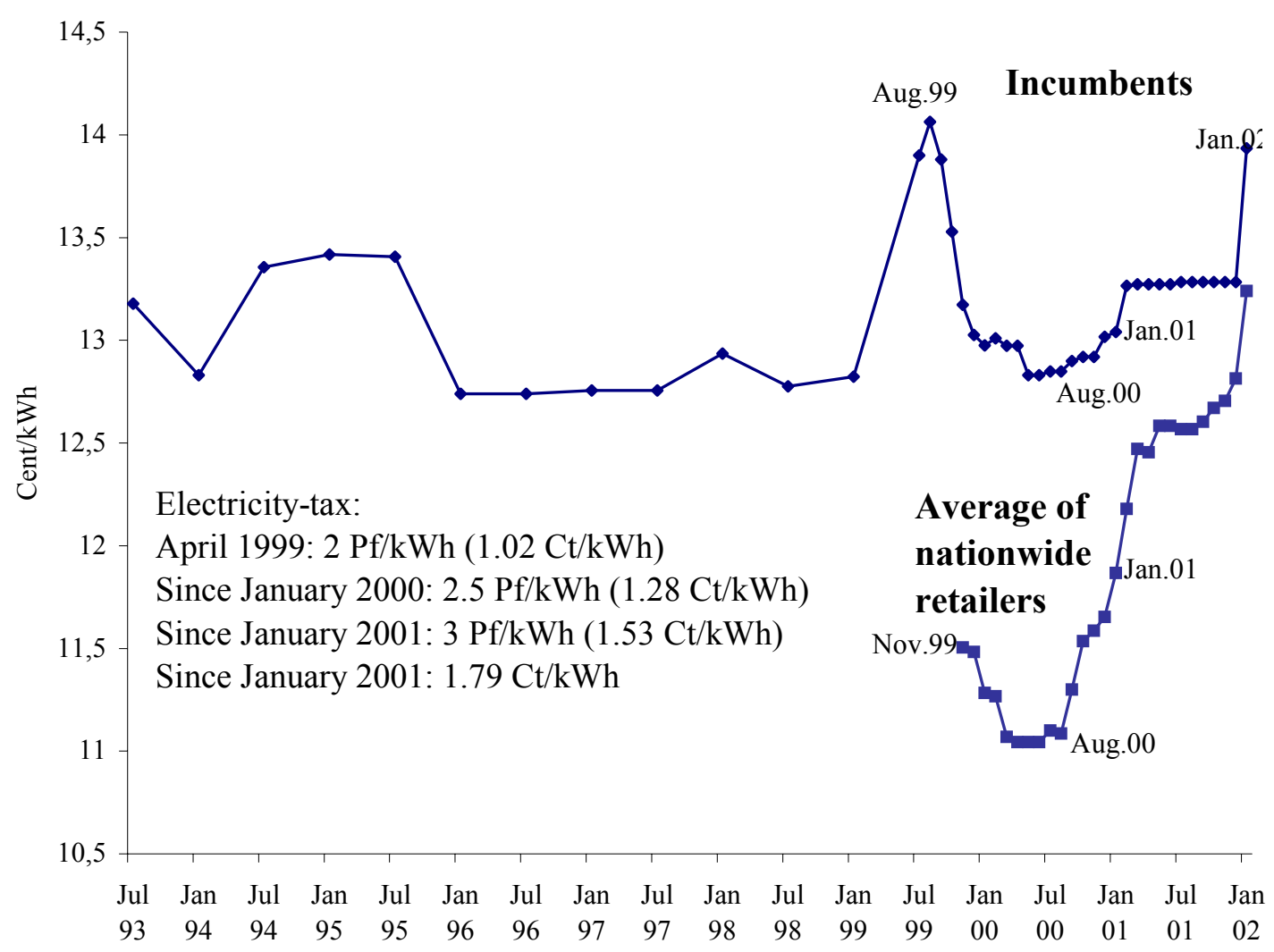

Source: Brunekreeft, 2003, p. 220, based upon Brunekreeft, Keller, 2000, p. 23. 
Figure 4: Price development in German electricity retail markets

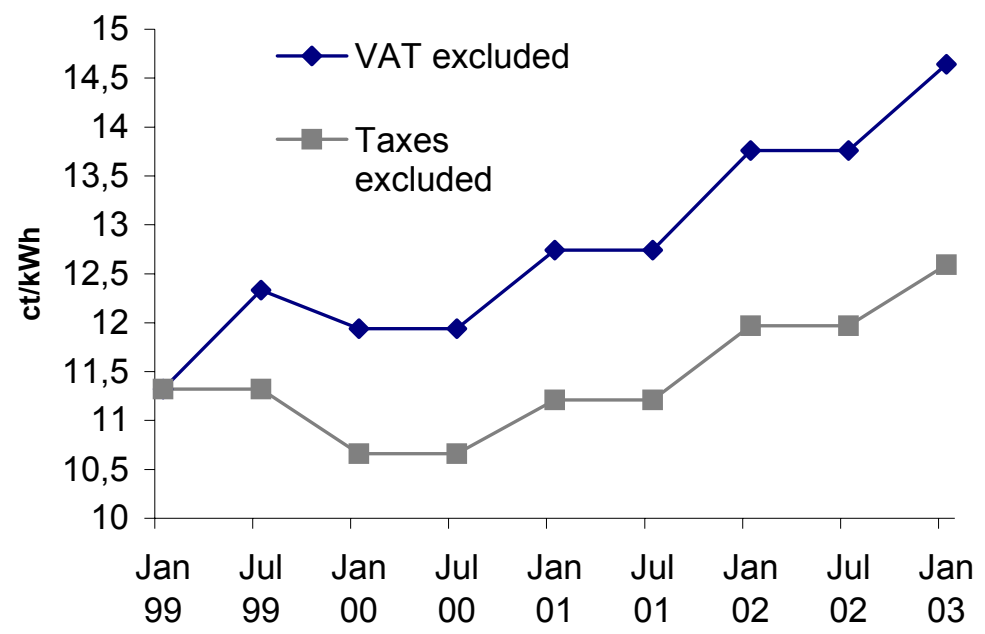

Source: Eurostat, several years 


\section{CESifo Working Paper Series}

(for full list see www.cesifo.de)

1124 Chang Woon Nam and Doina Maria Radulescu, Does Debt Maturity Matter for Investment Decisions?, February 2004

1125 Tomer Blumkin and Efraim Sadka, Minimum Wage with Optimal Income Taxation, February 2004

1126 David Parker, The UK's Privatisation Experiment: The Passage of Time Permits a Sober Assessment, February 2004

1127 Henrik Christoffersen and Martin Paldam, Privatization in Denmark, 1980-2002, February 2004

1128 Gregory S. Amacher, Erkki Koskela and Markku Ollikainen, Deforestation, Production Intensity and Land Use under Insecure Property Rights, February 2004

1129 Yin-Wong Cheung, Javier Gardeazabal, and Jesús Vázquez, Exchange Rate Dynamics: Where is the Saddle Path?, February 2004

1130 Alberto Alesina and Guido Tabellini, Bureaucrats or Politicians?, February 2004

1131 Gregory S. Amacher, Erkki Koskela, and Markku Ollikainen, Socially Optimal Royalty Design and Illegal Logging under Alternative Penalty Schemes, February 2004

1132 David M. Newbery, Privatising Network Industries, February 2004

1133 Charles Yuji Horioka, The Stagnation of Household Consumption in Japan, February 2004

1134 Eiji Fujii, Exchange Rate Pass-Through in the Deflationary Japan: How Effective is the Yen's Depreciation for Fighting Deflation?, February 2004

1135 Mark M. Spiegel and Nobuyoshi Yamori, Determinants of Voluntary Bank Disclosure: Evidence from Japanese Shinkin Banks, Febrary 2004

1136 Robert Dekle and Kenneth Kletzer, Deposit Insurance, Regulatory Forbearance and Economic Growth: Implications for the Japanese Banking Crisis, February 2004

1137 Takatoshi Ito and Kimie Harada, Bank Fragility in Japan, 1995-2003, February 2004

1138 Kunio Okina and Shigenori Shiratsuka, Policy Duration Effect under Zero Interest Rates: An Application of Wavelet Analysis, February 2004

1139 Francine D. Blau and Lawrence M. Kahn, Do Cognitive Test Scores Explain Higher U.S. Wage Inequality?, February 2004 
1140 Michael Rauscher, Economic Growth and Tax-Competing Leviathans, February 2004

1141 Ernst Fehr and Jean-Robert Tyran, Money Illusion and Coordination Failure, February 2004

1142 Ingo Vogelsang, Network Utilities in the U.S. - Sector Reforms without Privatization, March 2004

1143 Marc-Andreas Muendler, Estimating Production Functions When Productivity Change is Endogenous, March 2004

1144 Sascha O. Becker, Samuel Bentolila, Ana Fernandes, and Andrea Ichino, Job Insecurity and Children's Emancipation, March 2004

1145 Pascalis Raimondos-Møller and Alan D. Woodland, Non-Preferential Trading Clubs, March 2004

1146 Robert Fenge and Matthias Wrede, EU Regional Policy: Vertical Fiscal Externalities and Matching Grants, March 2004

1147 Chi-Yung Ng and John Whalley, Geographical Extension of Free Trade Zones as Trade Liberalization: A Numerical Simulation Approach, March 2004

1148 Marc-Andreas Muendler, Trade, Technology, and Productivity: A Study of Brazilian Manufacturers, 1986-1998, March 2004

1149 Eugene Beaulieu, Vivek H. Dehejia, and Hazrat-Omar Zakhilwal, International Trade, Labour Turnover, and the Wage Premium: Testing the Bhagwati-Dehejia Hypothesis for Canada, March 2004

1150 Giorgio Brunello and Francesca Gambarotto, Agglomeration Effects on EmployerProvided Training: Evidence from the UK, March 2004

1151 S. Brock Blomberg, Gregory D. Hess, and Athanasios Orphanides, The Macroeconomic Consequences of Terrorism, March 2004

1152 Bodo Sturm and Joachim Weimann, Unilateral Emissions Abatement: An Experiment, March 2004

1153 Wolfgang Ochel, Welfare-to-Work Experiences with Specific Work-First Programmes in Selected Countries, March 2004

1154 Jan K. Brueckner and Eric Pels, European Airline Mergers, Alliance Consolidation, and Consumer Welfare, March 2004

1155 Aaron Tornell, Frank Westermann, and Lorenza Martínez, NAFTA and Mexico's Economic Performance, March 2004

1156 George Economides, Sarantis Kalyvitis, and Apostolis Philippopoulos, Do Foreign Aid Transfers Distort Incentives and Hurt Growth? Theory and Evidence from 75 Aid-recipient Countries, March 2004 
1157 Robert Fenge and Volker Meier, Are Family Allowances and Fertility-related pensions Siamese Twins?, March 2004

1158 Bruno S. Frey, Simon Luechinger, and Alois Stutzer, Valuing Public Goods: The Life Satisfation Approach, March 2004

1159 Jerome L. Stein and Guay C. Lim, Asian Crises: Theory, Evidence, Warning-Signals, March 2004

1160 Romain Ranciere, Aaron Tornell, and Frank Westermann, Crises and Growth: A ReEvaluation, March 2004

1161 Assaf Razin and Efraim Sadka, Transparency, Specialization and FDI, March 2004

1162 Ludger Woessmann, How Equal Are Educational Opportunities? Family Background and Student Achievement in Europe and the United States, March 2004

1163 B.M.S. van Praag and Barbara E. Baarsma, Using Happiness Surveys to Value Intangibles: The Case of Airport Noise, March 2004

1164 Aaron Tornell, Frank Westermann, and Lorenza Martínez, The Positive Link Between Financial Liberalization, Growth, and Crises, March 2004

1165 Helge Berger and Carsten Hefeker, One Country, One Vote? Labor Market Structure and Voting Rights in the ECB, March 2004

1166 Clemens Fuest and Martin Kolmar, A Theory of User-Fee Competition, March 2004

1167 Friedrich Schneider and Robert Klinglmair, Shadow Economies around the World: What Do We Know?, April 2004

1168 Horst Raff and Nicolas Schmitt, Exclusive Dealing and Common Agency in International Markets, April 2004

1169 M. Hashem Pesaran and Allan Timmermann, Real Time Econometrics, April 2004

1170 Sean D. Barrett, Privatisation in Ireland, April 2004

1171 V. Anton Muscatelli, Patrizio Tirelli and Carmine Trecroci, Can Fiscal Policy Help Macroeconomic Stabilisation? Evidence from a New Keynesian Model with Liquidity Constraints, April 2004

1172 Bernd Huber and Marco Runkel, Tax Competition, Excludable Public Goods and User Charges, April 2004

1173 John McMillan and Pablo Zoido, How to Subvert Democracy: Montesinos in Peru, April 2004

1174 Theo Eicher and Jong Woo Kang, Trade, Foreign Direct Investment or Acquisition: Optimal Entry Modes for Multinationals, April 2004 
1175 Chang Woon Nam and Doina Maria Radulescu, Types of Tax Concessions for Attracting Foreign Direct Investment in Free Economic Zones, April 2004

1176 M. Hashem Pesaran and Andreas Pick, Econometric Issues in the Analysis of Contagion, April 2004

1177 Steinar Holden and Fredrik Wulfsberg, Downward Nominal Wage Rigidity in Europe, April 2004

1178 Stefan Lachenmaier and Ludger Woessmann, Does Innovation Cause Exports? Evidence from Exogenous Innovation Impulses and Obstacles, April 2004

1179 Thiess Buettner and Johannes Rincke, Labor Market Effects of Economic Integration The Impact of Re-Unification in German Border Regions, April 2004

1180 Marko Koethenbuerger, Leviathans, Federal Transfers, and the Cartelization Hypothesis, April 2004

1181 Michael Hoel, Tor Iversen, Tore Nilssen, and Jon Vislie, Genetic Testing and Repulsion from Chance, April 2004

1182 Paul De Grauwe and Gunther Schnabl, Exchange Rate Regimes and Macroeconomic Stability in Central and Eastern Europe, April 2004

1183 Arjan M. Lejour and Ruud A. de Mooij, Turkish Delight - Does Turkey's accession to the EU bring economic benefits?, May 2004

1184 Anzelika Zaiceva, Implications of EU Accession for International Migration: An Assessment of Potential Migration Pressure, May 2004

1185 Udo Kreickemeier, Fair Wages and Human Capital Accumulation in a Global Economy, May 2004

1186 Jean-Pierre Ponssard, Rent Dissipation in Repeated Entry Games: Some New Results, May 2004

1187 Pablo Arocena, Privatisation Policy in Spain: Stuck Between Liberalisation and the Protection of Nationals' Interests, May 2004

1188 Günter Knieps, Privatisation of Network Industries in Germany: A Disaggregated Approach, May 2004 